Volume 5, Issue 2

September 2012

\title{
Value in brokenness: fractured subjectivities in contemporary American Telefantasy
}

\author{
CHARLOTTE HOWELL, Georgia State University
}

\begin{abstract}
This paper analyses the articulation of diegetic value in broken subjectivities represented in recent American Telefantasy programmes. In Fringe (2008- ) and Dollhouse (2009-2010), protagonists and main characters articulate a sense of worth in their fractured, multiple, and/or cyborg identities, though this narratively articulated value is often couched in an ambivalence created by the narrative. This article attends to the questions of gender and agency in these shows' post-humanist configurations of subjectivities.
\end{abstract}

\section{KEYWORDS}

Cartesian duality, gender, posthumanism, postmodernism, subjectivity, Telefantasy.

\section{Introduction}

The idea of "fracture" connotes loss and brokenness. Apply that idea to the concept of human identity, and such a connotation appears more starkly. If there is no one, whole self, then how can we know ourselves? This question is both philosophical and rhetorical, but it forms a foundation for many postmodernist theorists and subsequent posthumanist theorists. However, this question continues the implication of loss in fracture, of movement away from a seemingly more ideal past in which a subject faced less potential for multiplicity, mutability, and fracture. Instead of addressing the mediated articulations of fractured subjectivities in American Telefantasy as symptomatic of a postmodern loss, Fringe (2008- ) and Dollhouse (2009-2010) predominantly present female main characters that articulate through dialogue a sense of value - defined operatively by positive articulations within the text - in their fractured, multiple, and/or cyborg identities.

The characters can make this claim in concrete terms because of the fantastic diegetic worlds in which they live, worlds of Telefantasy. Catherine Johnson defines Telefantasy as a broad term, drawing on fan discourses, for the non-verisimilitudinous - that is, those genres that defy realist conventions - television genres of Science Fiction, Fantasy, and Horror (Johnson, 2005: 1). This broad term allows for greater flexibility of meaning and aim. The worldbuilding afforded by Telefantasy can portray material representation of a "self" through serums or brain parts that contain identities, souls that are tangible and visible, or 
subjectivities that were once organic but now are cybernetically (re)constructed. Some genre scholars may argue that 'science fiction is, at least in our time, the privileged generic tendency for utopia; that is, for those anticipatory figurations of an unalienated future that constitute the deepest critical truth of which art is capable. More difficult to attain even than critique in its negative, demystifying dimension, utopia has never been so desperately needed as it is now, in our postmodern environment that ruthlessly tends toward total reification' (Freedman, 2000: 199). Telefantasy as Johnson more broadly defines it, however, folds Fantasy and Horror into a similar position as a critical genre. Telefantasy aligns all three genres with Tsvetan Todorov's conception of the fantastic as a moment of hesitancy in which subversion of norms is possible (Todorov, 2004: 136). Johnson's definition of Telefantasy not only provides room for addressing the genre hybridity of non-verisimilitudinous television dramas but also that Telefantasy 'is seen to have subversive potential because it represents the "unreal"' in a way that potentially challenges viewers" norms and assumptions (Johnson, 2005: 7). Telefantasy's genre elements in these shows - mad scientists and cyborgs of both mind and body - allow for the dramatisation and literalisation of the debates about "self," identity, humanity, and personhood that have intrigued philosophers and theologians in the postmodern era and beyond.

Johnson argues in Telefantasy that 'all texts that represent the fantastic ask questions that push the boundaries of socio-cultural verisimilitude,' that is, that question reality as we know it, challenging the status quo in potentially subversive ways (Ibid.: 4). This, I argue, is what these Telefantasy texts are doing, and one of the boundaries they are pushing against is the increasingly politicized and broadening biological conception of personhood, informed by religious ideas of the soul.

At the time of this writing, 33 states in the U.S. have introduced so-called "personhood" amendments which would grant legal standing to embryos as well as posing a threat to in vitro fertilization processes (Kilelman and Jenco, 2012). "Personhood," which had previously been a somewhat arcane legal term has now been discursively tied to the antichoice movement and the political campaigns that seek to appeal to that movement's base: the "Religious Right," a powerful evangelical Christian bloc of the Republican Party, and the "Tea Party," an extreme strain of politically conservative citizens and politicians who advocate minimal state and federal intervention. Personhood USA is a conservative interest group that asked the 2012 Republican Presidential nominees to sign a pledge to recognize personhood 'from conception until natural death,' which the majority of candidates (Michelle Bachmann, Rick Santorum, Newt Gingrich, Ron Paul, and Rick Perry) did (Ashley, 2011). Personhood is no longer a philosophical debate; it is a codified link between body and soul that adheres to Judeo-Christian tenets of life as an extension of the soul. The interest group's cooptation of the term "personhood" associates it in the cultural imaginary with the religious values that underwrite this element of the American anti-choice lobby that positions life as an essential subject beginning at conception. Valerie Hartouni describes the power wielded by 
Volume 5, Issue 2

September 2012

discussions of reproductive practices in Cultural Conceptions: On Reproductive Technologies and the Remaking of Life. She writes:

New reproductive practices have also been brought into the service of dominant cultural narratives and work both to facilitate and fortify them... The rescripting that is required, however, for these new practices to perform such work, to function ideologically, is considerable. And it is at such moments in particular-typically when the law is called upon to locate nature or determine which "natural facts' are "truly" natural and therefore determinant - that the production or, as the law seems generally to view it, "presence" of monsters [biological aberrations] is made visible. (Hartouni, 1997: 115)

With this insight, Hartouni helps explain the relationship between the pattern in Telefantasy embracing fractured subjectivities, and state legislatures across the country that are facing attempts at redefining legal standing for reproduction at its most inchoate. Telefantasy programmes are making the 'monsters' more visible through valorized broken subjectivities that challenge religious doctrine of the immortal soul, of Cartesian duality, and of the assumed desire for unity. I am not trying to imply causation with this claim, merely an affinity of anxieties expressed in two seemingly divergent fields of culture: popular entertainment and national (reproductive) politics.

Hartouni further situates reproductive discourses in relation to concerns of humanism and subjectivity. She identifies 1990s discussions of cloning as stories that 'ostensibly reset and settle highly permeable, continuously shifting boundaries that maintain the coherence and exclusivity of what is the ideological centerpiece of Western thought, humanism's unique, self-contained, self-determining individual' (Ibid.: 118). Following this line of thought, the current atmosphere of politicized personhood may also be attempting to settle the boundaries of human subjectivity, seeking to create unity and stability within a postmodern moment of fracture. As the concept of a person appears to be inching closer to a religious - particularly Judeo-Christian - definition, one that implies inherent unity of body and soul (and subjectivity) that can be found at the very inception of life, the Telefantasy programmes in this study offer an alternative - one that has the potential to subvert not only this increasingly present religious idea of what a person is, but also supposedly non-religious Enlightenment rationality, and both concepts' relationships to Cartesian duality.

My argument engages with the ideas of humanism, religion, and postmodernity to get to posthumanist thought. Posthumanist scholarship engages with unsettled, porous, and mutable conceptions of humanity that trouble the ostensibly clear boundaries between humans and animals or humans and machines. This strain of thought undergirds the subversive potential of Telefantasy's fractured subjectivities. I focus particularly on textual and genre analysis in this project. In doing so, I aim to articulate the texts' ambivalent and occasionally ambiguous challenge to assumptions of unity as a metaphysical goal for a subject and how such debates 
Volume 5, Issue 2

September 2012

are writ in the (predominantly, female) bodies of characters. These television shows further question whether the brokenness found in fractured subjectivities is inherently a loss, as many theorists consider it. Characters in these contemporary American Telefantasy programmes represent an alternative that challenges the articulation of subjectivity in Judeo-Christian framings of the essential soul, which appear increasingly emphatic in our society. They tell us that there can be value in brokenness without progress toward unity. An organic meeting of body and soul might not just be anachronistic but undesirable as well.

\section{The soul, the mind, and the desire for unity}

From early scholars in the field of religious studies to the ongoing debates on "personhood," the soul is a concept steeped in a desire for continuity. Whether it be about eternal longevity as in Christian dogma or E.B. Tylor's conception of the human soul as the modern "survival" of primitive animism that imbued all objects with divine spirit, the concept of the soul connects back to the past and reaches forward into perpetuity but remains essentially whole, and more importantly, natural. As John Cooper surveys in his article 'Biblical Anthropology and the Body-Soul Problem,' many recent philosophers and theologians reinterpret JudeoChristian doctrine in holistic or monistic terms, but he argues that 'the best reading of Scripture still yields the teaching that human persons continue to exist, probably consciously, between death and the final resurrection... [entailing] that humans are so constituted that they can exist temporarily without physical organisms' (Cooper, 2001: 218-9). Such an understanding of scripture is seemingly commonsense among the vocal American publics that support organizations such as Personhood USA, and it privileges the concept of an essential self that flows from the soul and its unity (with the divine). This concept is naturalized in contemporary conservative American society, largely through politicians and public figures who conceptualize America's founding fathers and documents as essentially Christian. During debates over Texas's public school curriculums, such conceptions were placed in the spotlight. Gail Lowe, the chairwoman of the Texas board of education during the debate said, 'Many of us recognize that Judeo-Christian principles were the basis of our country and that many of our founding documents had a basis in Scripture... I think it will become evident to students that the founders had a religious motivation' (Shorto, 2010). Figures like Lowe are prevalent in American culture and buttress the alignment of JudeoChristian ideology and certain strands of American political culture that is evident in recent discussions of women's bodies as contested public sites.

A similar drive for unity but of mind and body (and continuity of thought) shapes the assumed goals of American individualism from the Enlightenment rationality that influence the Deist founding fathers like Thomas Jefferson. Cartesian duality, the split between mind/soul and body, was seen as an obstacle to be overcome by rationality that would tame the bodily beast under the auspices of the mind. Both Dr. Jekyll and Mr. Hyde had their place, but ultimately such bifurcation would lead to destruction. Descartes' conception of a 
Volume 5, Issue 2

September 2012

person "is a combination, or "union" as he called it, of an immaterial soul and a human body composed of ordinary matter' (Kim, 2001: 31). Unity is central to the idea of personhood under Cartesian dualism. Such an idea Brian Leftow traces back to Aquinas whose perspective on dualism he explains thusly: 'Biology does not deal with souls but it presupposes what souls do: the presence of souls gives biology its subject matter' (Ibid.: 128). For these Cartesian thinkers and many like them, the immaterial soul or mind is paramount and necessary for bodily functioning, and the union of the duality is what allows for existence.

This reliance on union through dualism also provides room for religious ideation of the soul. As John Foster argues in 'A Brief Defense of the Cartesian View,'

biological life begins at conception [. . .] but it is hard to see how this process, or the subsequent development of the organism, could create an additional nonphysical substance and functionally attach it to the organism in the relevant way. The answer, it seems to me, is that we should explain these things by appeal to the creative role of God [.. .] Theism enables the Cartesian to explain the existence and role of the nonphysical subjects; and, because this is the only satisfactory explanation, the argument for the Cartesian view becomes itself a powerful argument for the existence of God. (Foster, 2001: 29)

Thus, unity and wholeness were still conceived as the goal of both religion and rationality, a goal that continues to influence dominant social norms, even as postmodernity made such a goal seem improbable or impossible to reach. For these historic and continuing influences, a fractured self is seen as symptomatic of a larger problem - examples include impiety, irrationality, or postmodern rupture. This symptomatic framing reiterates the idea of fracture as a problem to be solved, potentially through legislation that dictates a whole identity at conception

Posthumanism, however, brings flexibility to the debate by destabilising not necessarily the goal of unity, but the subject who is seeking that goal: the idea of the unified human. Though, as Cary Wolfe indicates, posthumanism is a term still being defined and codified for example, in relation to transhumanism, or in opposition to embodiment, or in favour of material corporeality. I am drawing most strongly from Donna Haraway's seminal posthumanist work, 'A Manifesto for Cyborgs,' to conceptualize an optimistic approach to fractured subjectivities (Wolfe, 2010: xv). Haraway is useful here because she, too, questions the goal of unity by approaching the idea of a cyborg as a constructed, poststructuralist idea of a self that is both machine and organism and that 'skips the step of original unity, of identification with nature in the Western sense' (Haraway, 2004: 9). Haraway also operates in dialogue with religion, or at least religious language. She describes her manifesto as 'an effort to build an ironic political myth faithful to feminism, socialism, and materialism. Perhaps more faithful as blasphemy is faithful than as reverent worship and identification. 
Volume 5, Issue 2

September 2012

Blasphemy has always seemed to require taking things very seriously' (Ibid.: 7). Haraway's blasphemy is optimistic, finding promise in the progressive potential attached to cyborg subjectivity. Her theory is explicitly feminist, situating the cyborg as a post-gender organism that is aligned with historically othered female bodies (Ibid.: 9). Haraway's feminist foundation highlights the association between colonised female bodies and cyborg identities that recurs in my analysis of Fringe and Dollhouse. Her framework links with Angela McRobbie's postmodern feminist approach to fractured subjectivity, stated in her article 'Feminism, Postmodernism, and the "Real Me".'

Unlike many pessimistic postmodern theorists, McRobbie - like Haraway - grounds her approach to such fracturing in a kind of optimism. She writes how 'the feminist social self, it might be suggested, is an amalgam of fragmented identities formed in discourse and history' (McRobbie, 2006: 529). Where McRobbie discusses fragmentation as a result of discursive panoply, Haraway challenges the idea of unity not only by using a figure that bypasses that seemingly natural step but also by destabilizing binaries. She writes, 'late-twentieth-century machines have made thoroughly ambiguous the difference between natural and artificial, mind and body, self-developing and externally designed, and many other distinctions that used to apply to organisms and machines' (Haraway, 2004: 11). This destabilisation not only blurs the boundaries between the concepts she mentions but also makes incorporation into a unified whole seemingly impossible because the concepts are so muddied, multiple, flexible, and overlapping.

Haraway valorises the cyborg figure, describing it as a 'world-changing fiction,' which connects back to Hartouni's discussion of biological 'monsters' (Ibid.: 7). Hartouni concludes her book by writing, '[the discursively constructed monsters of reproduction] are, nevertheless, the monsters that emerge when extant borders, categories, identities, and relations are breached and whose very presence or production permits these borders to regain their coherence and exclusivity... perform[ing] the important cultural function of securing what the practice destabilizes' (Hartouni, 1997: 132). In this selection, Hartouni articulates the ambivalent position of the rupture wrought by reproductive 'monsters.' They emerge from the progressive potential of liminality, but there are limits to that potential in that it is often swiftly closed and reintegrated into the status quo. Such openness to the worth of the aberrant and its subversive potential aligns both Haraway and Hartouni with American Telefantasy's ability to challenge socio-cultural norms, even as Hartouni is less celebratory and more hesitant than Haraway's polemic manifesto, which ignores the suturing of such ruptures. Fringe and Dollhouse have the potential to be world-changing fictions in their diegetic articulation of valuable monsters and worthy fractures, but the potential remains couched in the polysemy of television text generally, and Telefantasy particularly.

These shows not only challenge the assumed religious or rational goal of unity but also the presumed "problem" of postmodernity. For them, fractured subjectivities - cyborgs of mind, body, machine, affect, and/or soul - are not an answer to a problem; they are an indication that there might not be a problem to be solved. And here is where I depart somewhat from 
Volume 5, Issue 2

September 2012

Haraway's pure optimism. Instead of wholly lauding the fracture, even when the shows appear to celebrate it, I attend to the shows' ambivalences and ambiguity created by the oftpresent tension between the characters' dialogue and the narrative's presentation of and commentary on their actions. Moreover, ambivalence is amplified when we realise that most of these fractured subjectivities are forced on female bodies, attaching these representations to the anxieties expressed in the political "war on women" that includes personhood amendments. Female characters in these shows must, and do, navigate their fractured identities in ways that sometimes obfuscate their subjugation in order to find empowerment and value in their brokenness. The Telefantasy cyborgs in this paper are not part of the singularity, the collective awareness of networked machines. They can and do manifest a variation of the singularity inside themselves, a microcosmic production of an internal network of fractured parts of a self that is more desirable than a unified self. The parts are still separate, fractured, but connected in a sense of self that thrives on the liminal spaces created by the fracture and the potential therein.

\section{Brains, bodies, and "organic" fracture}

In Fringe, identity is created and stored in organic matter: brains and bodies. Fringe draws on the model of The X-Files (1993-2002) by presenting some procedural mysteries associated with the main characters who work for the Federal Bureau of Investigation, and which form a larger serial narrative that includes parallel universes and alternate timelines. Protagonist Special Agent Olivia Dunham (Anna Torv) is an exceptional agent, made more exceptional by her own history with the "mad science" she and the Fringe team investigate: as a child, she had been dosed with a drug, Cortexiphan, which enhanced her latent psychic abilities. The man who led the Cortexiphan trials was Walter Bishop (John Noble), a scientist who crossed into a parallel universe to cure an ailing alternate version of his dead son, Peter (Quinn Lord), kidnapping him in the process. The show follows adult Peter (Joshua Jackson), Olivia, and Walter as they investigate cases of "fringe" science.

In Fringe, a soul or "original"1 self may interact with the spaces created by fracture, but medical materialist ${ }^{2}$ explanations for characters' broken subjectivities ground them. For Olivia Dunham, her sense of self has been medically overwritten no less than four times in as many seasons: twice as "other" Olivias and twice as men inhabiting her mind and body. Dialogue explains how the male subjectivities implanted in her are eventually purged completely, whilst the "other" Olivias become a permanent part of her "self," though never entirely integrated. Fringe also relies on medical materialism to illustrate the diegetic value in Walter Bishop's brokenness. By imbuing his missing brain matter with his undesirable characteristics, the programme's narrative implicitly locates identity independent of a soul, grounding the questions of identity in medically alterable bodily states.

Fringe's medical materialist exploration of fractured subjectivities, however, remains most clearly - or, at least, most frequently apparent - in the character of Olivia. I will now 
Volume 5, Issue 2

September 2012

examine each of the four iterations of her "self" which are imprinted onto Olivia. It is worth noting here, however, that the passive voice in the previous sentence is deliberate because Olivia's fracturing is most often something done to her. Similarly to the discussions of reproduction mentioned earlier, Olivia's body is the object on which the majority of the discussions of fractured subjectivity act. The repeated forced-fracturing Olivia experiences injects ambivalence into the narrative, tempering the potential for progress with questions of power, and a particularly gendered bifurcation of agency.

In the first season, Olivia ventures into the mind of her dying partner and lover, John Scott (Mark Valley), through a liberal dosing of LSD, connected brainwaves, and sensory deprivation. She inadvertently brings parts of his consciousness into her mind after the experiment ends (and Scott dies) (1.01, 'Pilot'). His memories merge with hers, to the point where she cannot differentiate between the two. Though she does eventually confront him within her mind, and purges him from her self, his memories and the knowledge she gained from them remain a part of her mind, even if they are no longer overwriting her (1.13, 'The Transformation'). This is the first material example of Olivia's fractured identity, and the theme of illustrating fracture through implanting other subjectivities - not just memories but also personalities, consciousness, and even a soul - into the character of Olivia continues throughout the series.

In season three, another wholly "other" subjectivity imprints itself over Olivia but, instead of doing so via memories, scientist William Bell (Leonard Nimoy) pulls his soul into Olivia's body by way of harmonic resonance between a "soul magnet" unwittingly imbibed by Olivia, and a corresponding, paired magnet in the dead (and disintegrated) Bell (3.16, 'Os'). Even this, one of the rare references on Fringe to the soul as an actual, manipulable thing, uses medical materialist means to fracture and bury Olivia's subjectivity, pairing religious and scientific language and concepts within the dialogue. Left inside Olivia for too long, Bell's soul could overpower her identity. To ensure that this does not occur, LSD and synched brainwaves are used to bring a potential saviour, Peter, into Olivia's mind to confront the offending, overwriting “other” (2.19, 'Lysergic Acid Diethylamide'). Peter enters Olivia's mind, a space rendered through animation, and must find Olivia among the hostile hoards of people who represent her memories and defenses. Peter first encounters a simulation of Olivia as a test of his loyalty and ability to differentiate between the Olivia he loves and any "pretenders." This simulation also acts as a manifestation of Olivia's fractured and somewhat multiple identity. Eventually, Olivia retakes control of her mind and William Bell is extracted, purging her brain and body of his consciousness as she did with John Scott - by asserting her own sovereignty over her mind. These two "other" - notably male personalities were not Olivia and thus are extracted. However, when the implanted subjectivities are versions of Olivia - and, like in her mindscape, manifestations of her fractured subjectivity - no overt purging or extraction occurs.

In the third season, whilst in an alternative universe, Olivia is kidnapped and made to believe that she is actually her alternate self. This is achieved by the implanting of alternate- 
universe-Olivia's memories, personality and even romantic attachments, through a chemical concoction delivered via syringe (3.01, 'Olivia'). The chemical acts as a retrovirus, rewriting Olivia's memories and personality until she no longer remembers her original-universe self. When the overwrite does not completely hold, however, she projects the memories of her "original" subjectivity into a visual hallucination not of herself but of Peter, the man she loves, even as she claims not to know him (3.03, 'The Plateau'). This illustrates Olivia's fractured self by proxy and perhaps even by transference; Olivia unconsciously projects the part of herself not affected by the implanted memories as an other being outside of her body, but within her mind. She wraps that element of herself in the image of her male paramour, perhaps because that is how her fractured subjectivity first manifested: as the image of an autonomous John Scott in her mind. The idea of a multiple or fractured self, even as she is living the life of her alternate-universe counterpart, is a difficult concept to confront, so Olivia, like the Telefantasy viewer, can experience it through symbolic displacement into a more familiar yet defamiliarised symbolic figure.

Although Olivia eventually becomes aware of her original-universe memories and the alternative-universe personality given to her, she is never said to be "cured" of the alternative-universe Olivia. Her original-universe self reasserts dominance but, if the implanted personality can be thought of as acting like a retrovirus, then Olivia, at least in part, was fundamentally (biologically) altered. Whilst John Scott and William Bell were purged, traces of alternate-universe Olivia's implanted subjectivity seem to persist. This illustrates the limits of Fringe's embrace of fragmentation: internal fragmentation is allowed to endure - but imposed "othering" through fracture must be fought. Similar to discussions of reproductive choice, men imposing their will over Olivia by forcing parts of their selves into hers can be rejected by Olivia's asserting agency over her body and (embodied) mind.

This silence on alternate-universe counterpart's subjectivity within Olivia's body contrasts with a more recent implantation - that of an Olivia Dunham from an alternate timeline. In season four, the narrative world of Fringe exists as if Peter had died as a child, yet Peter (as he had existed in the three previous seasons) unexpectedly reappears, drawn into reality by Olivia's love for him and her burgeoning psychic powers (re-awakened by her being covertly dosed with Cortexiphan once again). Eventually the iteration of Olivia that was the protagonist of the first three seasons reappears, too - overwriting the alternate-timeline Olivia's memories, personality, and even psychic abilities with her own more developed skills. Initially, both versions of Olivia's memories coexist, but this uneasy balance does not last long, as original-timeline Olivia's memories begin to overtake those of Olivia in the alternate-timeline. Yet, there is overlap, and there are some relationships forged by the alternate-timeline Olivia that the original-timeline Olivia seeks to maintain. Though the overwriting original-timeline Olivia is familiar to viewers as the "original" Olivia, in this new timeline she is actually yet another implanted subjectivity, joining the chorus of subjectivities housed within Olivia's Cortexiphan-saturated body: partially integrated but still a result of artificial and medical causation, and thus not unified. That state of being, according to Olivia, 
Volume 5, Issue 2

September 2012

is fine. She tells her adoptive mother, 'all of these memories and feelings that I'm experiencing, they're from a better version of me. I've decided to let things run their course,' which means letting the other Olivia overwrite the one that existed without loving Peter (4.15, 'A Short Story About Love'). To her mother's fear that her Olivia, "Olive," would be completely lost, Olivia responds, 'when the day comes, if I don't remember this [our family bond], I want you to try and build something with me. Don't give up on me' (Ibid.). Olivia articulates the value of the implanted and "false" memories in her attempt to hold the many parts of Olivia within herself, and in her attempt to maintain relationships forged by her various selves.

Where Olivia articulates her own sense of agency in valuing her fractured identity, Walter represents a similar diegetic valuing of brokenness but without as strong a sense of agency. Instead, he stands as an object lesson in the worthiness of fractured subjectivity, particularly one that is chosen, instead of forced on him. In the episode 'Grey Matters' (2.10), it is revealed that Walter's mental instability is caused by an earlier lobotomy that removed three small pieces of his brain which were then implanted into other people's in order to keep those pieces of Walter's brain viable. When Walter reconnects to his three brain bits, he transforms into a cold, aggressive, and arrogant man who is a far cry from the warm and loving (albeit befuddled) Walter familiar to the viewer. Olivia vocalises the symbolic connection between a "whole" Walter and a cold, amoral man when she tells Peter, "from what I know of your father, going crazy made him a better person. It certainly made him a better father' (Ibid.). Two seasons later, another character, Nina Sharp (Blair Brown), explains why Walter chose to have those pieces of his brain removed: 'I don't think he liked who he was becoming' (4.19, 'Letters of Transit'). Though Walter does not articulate his choice of brokenness, he chooses that state, and others who know him see it as an improvement. Within the programme's diegesis, Walter is portrayed as better man with parts of him scattered and separate - his brain literally fractured. His broken self is better than his unified self, but both are built in the brain.

Fringe articulates "organic" fractures of subjectivity throughout bodies and brains. Walter and Olivia are "organic" cyborgs in that their hybridity is of personality and corporeality instead of machinery. They illustrate the deconstruction of "original" and fractured selves, articulating fracture as better than any original, natural unity, and undermining the latter concept as a reality. Yet there appears to be a gendered hierarchy of agency created between these two "organic" cyborgs: Walter chooses his fracture and Olivia has it forced upon her. My other chosen Telefantasy text follows similar patterns and embraces similarly (even more explicitly) gendered politics, but does so in the framework of technologically constructed conceptions of a fractured self.

\section{Brains are mainframes: Technological fracture}


Volume 5, Issue 2

September 2012

In Dollhouse, technological cyborgs also deconstruct conceptions of "original" and fractured selves, and favour their fractured, cyborgian natures over an "original" organic self.

Moreover, as with Olivia on Fringe, the fracturing of subjectivities in these shows plays out on women's bodies, often at the behest of male desires. If personhood is a bodily attachment beginning at conception, these technological cyborgs undermine the validity of that conception of self by favoring a created, multiple, and fractured subjectivity that has little to do with the metaphysical soul. However, any sense of agency and self-articulation represented by these cyborgs is mired in ambivalence due to the associative narrative of male power overwriting (and, therefore, overpowering) female bodies.

"Echo" (Eliza Dushku) is a "doll," a human who has leased her body to the Rossum Corporation to be implanted with, then wiped of, various personalities tailored to rich (usually male) clients' fantasies. Most of the prominent dolls on Dollhouse are also female, emphasizing the colonisation of female bodies by men. The dolls' brains are like computers, given new programmes and set to a kind of "sleep" mode when inactive. Dolls are meant to be childlike, empty vessels when not imprinted with a personality, yet Echo begins to remember her previous identities and form a unique sense of self through her multiplicity - an identity that is separate from Caroline, the young woman who originally leased her body to Rossum (and who then became Echo). Echo articulates herself as a fractured, multiple subject who may, in fact, be a better being than her "original" version. Through a dialogue with her friend and love interest Paul Ballard (Tahmoh Penikett), Echo attempts to describe herself/selves:

I didn't like... the idea that Caroline might not be - I've been saving this body for her. But I'm not her... I'm not her. My name is Echo... It's not my other personas that make me feel what I feel... There's a lot of noise from the chorus girls, but they're not me. There is a me. (2.07, 'Meet Jane Doe')

Throughout the series, Caroline, the unified "original" self is portrayed as a myopic idealist who abdicated her agency and body to Rossum and is literally reduced to (the body of) a child in the first season finale (1.13, 'Epitaph One'), while Echo is the sacrificing, worthy saviour of humanity because of her fractured identity. Echo has the skills and empathetic understanding of every personality she has been implanted with (and, also, Caroline's) by the series' end, yet she remains "Echo." Caroline's supposed dominance and the assumed unity between body and mind do not overwrite Echo's chosen (fractured) identity. The Rossum Corporation tries to dictate her personhood based on a contract and a lease on her body, a narrative element that recalls controversies regarding the "war on women" - specifically, the power of male legislators to impose their will on women's bodies, and conceptions of bodily sovereignty. In Dollhouse, however, Echo adapts and thrives even after the patriarchal Rossum Corporation has attempted to impose its will over her body. 
Volume 5, Issue 2

September 2012

Echo's character path represents the potential value Dollhouse places on a fractured subjectivity: Echo can "be" hundreds of people, and still be herself - who saves the world because of her fractured identity. Caroline, on the other hand, gets people hurt or killed because of her unified sense of self, as an idealist with an unwavering and inflexible goal. Echo is depicted as possessing an ideal version of female agency, as she navigates the restrictions that male power attempts to enforce upon her. Moreover, Echo's ability to hold multiple subjectivities within herself provides a personal pyrrhic victory to conclude the series. After ten years of loving Paul but continuously pushing him away, Paul is killed and Echo is left bereft until another doll, Alpha (Alan Tudyk) provides her with a backup imprint of Paul's subjectivity. Echo imprints herself with the technologically constructed, downloadable "Paul" and is shown interacting with him within her own headspace. Though he is corporeally dead, some measure of his subjectivity lives on, not only as a part of Echo, but alongside Echo in her mind, due to her ability to access her own fractured subjectivities without fully integrating them. It is strongly suggested that Paul is autonomous even within Echo's mind, alluding to the power of the female body to conceive, hold, and nurture independent beings.

However, Dollhouse does not identify all fractured subjectivities as inherently better and, in fact, positions Echo as a unique example - one of only two dolls able to integrate and reconcile their various imprints. The series paints a dystopian image of forced, corporate cyber hybridity in two episodes set in 2020 ('Epitaph One' and 2.13, 'Epitaph Two: The Return'). In this portrayal of the future, the world is full of two types of doll - aggressive "butchers" and docile "dumb shows," all created as a result of Rossum's technology having run loose and unchecked. With most people liable to be imprinted remotely, the world is full of potentially dangerous cyborgs, humans who may not be who they appear (or believe themselves) to be. On an individual level, the dangers of fracturing is made evident through the character of Alpha who, similarly to Echo, experiences all of his imprints. Alpha responds quite differently, however. Instead of increased empathy, he becomes psychopathic and violent. Over time, Alpha overcomes the violence of his fractured subjectivity to become a hero, or at least a "lapsed" psychopath. However, this is achieved not through integration, but acceptance, and his learning to navigate the multiple subjectivities housed within his being. Despite this acceptance, Alpha chooses to give up his fractured self in exchange for his "original" identity, or at least to take the chance that he might be able to revert to a singular subjectivity (Ibid.).

'Epitaph Two' also provides an ambivalent representation of the dangers of fractured subjectivities in the form of a gang of tech-heads who literally wear USB flash drives of personalities and skill sets around their necks, "uploading" them when needed. They are mercenaries and a familiar dystopian representation of the problem of fractured subjectivity and the dangers of cyborgian identity: the loss of humanity and emotional connection. An addiction-like overreliance on this technology results in one doll's estrangement from his partner and their son. Another tech-head explains that unlike Echo or Alpha, one has to 
Volume 5, Issue 2

September 2012

remove something (mercy) each time new information (such weapons expertise) is uploaded. These cyborgs write themselves as "rulers of the wasteland," terminators with organic bodies.

These counterexamples to Echo's articulation of the worth of her own fractured subjectivity are extensions of the dystopic, dark, and paranoid underpinnings of Dollhouse, and could be read as a more prevalent theme of the show. Echo is but one possibility among a mass of destructive fracturing. Echo is the protagonist and, as such, her voice and agency carry weight within the programme's narrative. What characters say and how the narrative positions them can create ambivalence when representing fractured subjectivities, but the act of utterance for this alternative - thinking of fractured subjectivity as an identity worth embracing - can be subversive and, one can argue, certainly outside the norm.

Echo uses her technologically created cyborg identity to articulate what she perceives to be the value of a fractured subjectivity, even as she does so in a cyborg body imposed upon her by men. Her multiplicity and fracture allows her (and, potentially, Paul as well) to survive beyond death, to be reconceived as a new being, capable of holding on to a multitude of subjectivities, as well as her chosen sense of self.

\section{Conclusion}

Though predating the current furore surrounding the "war on women" in American politics, Fringe and Dollhouse narrativise and present underlying anxieties which can be seen in related discourses: the potential value in fractured and constructed subjectivities which challenge and potentially subvert strongly held beliefs regarding soul-based personhood. Both programmes represent a challenge to what many consider to be sacred cultural beliefs: the importance of souls, that they determine who we are, that there is some immaterial, essential, whole self that exists beyond the confines of the corporeal body. Instead, they offer an alternative, not only to this familiar and comforting conceptualisation of the self, but also to the postmodern repudiation of the possibility of stable subjectivity. Fringe and Dollhouse propose that, though our subjectivity may be fractured, a fractured subjectivity is better than a union of body and soul; that we can find value in our brokenness.

\section{References}

Ashley, K. (2011, December 15) 'Personhood Republican Presidential Candidate Pledge,' Personhood USA. Retrieved from http://www.personhoodusa.com/blog/personhoodrepublican-presidential-candidate-pledge [accessed 2012, May 15].

Cooper, J. (2001) 'Biblical Anthropology and the Body-Soul Problem' in Corcoran, K. (Ed.) Soul, Body, and Survival: Essays on the Metaphysics of Human Persons. Ithaca, NY: Cornell University Press. 
Volume 5, Issue 2

September 2012

Foster, J. (2001) 'A Brief Defense of the Cartesian View' in Corcoran, K. (Ed.) Soul, Body, and Survival: Essays on the Metaphysics of Human Persons. Ithaca, NY: Cornell University Press.

Freedman, C. (2000) Critical Theory and Science Fiction. Hanover, CT: Wesleyan University Press.

Haraway, D. (2004) 'A Manifesto for Cyborgs: Science, Technology, and Socialist Feminism in the 1980s' in The Haraway Reader. New York: Routledge.

Hartouni, V. (1997) Cultural Conceptions: On Reproductive Technologies and the Remaking of Life. Minneapolis, MN: University of Minnesota Press.

James, W. (1997) The Varieties of Religious Experience. New York: Touchstone.

Jameson, F. (2006) 'Postmodernism, or the Cultural Logic of Late Capitalism' in Durham, G. M. and Kellner, D. M. (Eds.) Media and Cultural Studies: Key Works (Revised Ed.). Malden, MA: Blackwell.

Johnson, C. (2005) Telefantasy. London: BFI.

Keilman, J. and Jenco, M. (2012, April 5) "Personhood" becomes ground for debate in Naperville,' Chicago Tribune. Retrieved from http://articles.chicagotribune.com/2012-0405/news/ct-met-naperville-fertilty-clinic-follo-20120405_1_ralph-kazer-ivf-fertilization [accessed 2012, May 15].

Kim, J. (2001) 'Lonely Souls: Causality and Substance Dualism' in Corcoran, K. (Ed.) Soul, Body, and Survival: Essays on the Metaphysics of Human Persons. Ithaca, NY: Cornell University Press.

Leftow, B. (2001) 'Souls Dipped in Dust' in Corcoran, K. (Ed.) Soul, Body, and Survival: Essays on the Metaphysics of Human Persons. Ithaca, NY: Cornell University Press.

McRobbie, A. (2006) 'Feminism, Postmodernism, and the "Real Me"' in Durham, G. M. and Kellner, D. M. (Eds.) Media and Cultural Studies: Key Works (Revised Ed.). Malden, MA: Blackwell.

Shorto, R. (2010, February 11) 'How Christian Were the Founders?' The New York Times. Retrieved from http://www.nytimes.com/2010/02/14/magazine/14texbooks-t.html [accessed 2012, October 5].

Todorov, T. (2004) 'The Fantastic: A Structural Approach to a Literary Genre' in Sandner, D. Fantastic Literature: A Critical Reader. Westport, CT: Praeger.

Wolfe, C. (2010) 'Introduction' in What is Posthumanism? Minneapolis, MN: University of Minnesota Press.

\section{Teleography}


Volume 5, Issue 2

September 2012

Dollhouse. (2009-2010) U.S.A.: 20 ${ }^{\text {th }}$ Century Fox Television/Boston Diva Productions.

- 'Epitaph One,' Dollhouse. Episode 1.13. Dir. David Solomon. Unaired. Available on Dollhouse: Season One [DVD]. Twentieth Century Fox.

- 'Meet Jane Doe,' Dollhouse. Episode 2.07. Dir. Dwight Little. Fox Network. 2009, December 11.

- 'Epitaph Two: The Return,' Dollhouse. Episode 2.13. Dir. David Solomon. Fox Network. 2010, January 29.

Fringe. (2008- ) U.S.A./Canada.: Warner Bros. Television/Bad Robot/Fringe Element Films/FB2 Films.

- 'Pilot,' Fringe. Episode 1.01. Dir. Alex Graves. Fox Network. 2008, September 9.

- 'The Transformation,' Fringe. Episode 1.13. Dir Brad Anderson. Fox Network. 2009, February 3.

- 'Grey Matters,' Fringe. Episode 2.10. Dir. Jeannot Szwarc. Fox Network. 2009, December 10.

- 'Olivia,' Fringe. Episode 3.01. Dir. Joe Chappelle. Fox Network. 2010, September 23.

- 'The Plateau,' Fringe. Episode 3.03. Dir. Brad Anderson. Fox Network. 2010, October 7.

- 'Os,' Fringe. Episode 3.16. Dir. Brad Anderson. Fox Network. 2011, March 11.

- 'Lysergic Acid Diethylamide,' Fringe. Episode 3.19. Dir. Joe Chappelle. Fox Network. 2011, April 15.

- 'A Short Story About Love,' Fringe. Episode 4.15. Dir. J.H. Wyman. Fox Network. 2012, March 23.

- 'Letters of Transit,' Fringe. Episode 4.19. Dir, Joe Chappelle. Fox Network. 2012, April 20.

The X-Files. (1993-2002) U.S.A./Canada: 20th Century Fox Television/Ten Thirteen Productions/X-F Productions.

\footnotetext{
${ }^{1}$ I use "original" in quotes throughout the paper in order to signal its use under erasure, drawing from Derrida, as most instances of an "original" self deconstruct the concept. I similarly use quotation marks for terms like "real" or "fake."

${ }^{2}$ I use the terms "medical materialist" and "medical materialism" in this paper to represent a scientific, medical rationale as an alternative to Divine origins for extraordinary experience. I am drawing from William James' use of the term and its dichotomy in The Varieties of Religious Experience (1997).
} 